\title{
Drug therapy for people with mental disorders in the view of nursing professionals
}

\author{
A terapêutica medicamentosa às pessoas com transtorno mental na visão de profissionais da \\ enfermagem \\ La terapéutica medicamentosa a personas con trastorno mental desde la perspectiva de los \\ profesionales de enfermería
}

\author{
Camila Bonfim de Alcântara ${ }^{1}$ \\ Fernanda Carolina Capistrano ${ }^{1}$ \\ Juliana Czarnobay ${ }^{1}$ \\ Aline Cristina Zerwes Ferreira ${ }^{1}$ \\ Tatiana Brusamarello ${ }^{1}$ \\ Mariluci Alves Maftum ${ }^{1}$
}

1. Universidade Federal do Paraná.

Curitiba, PR, Brasil.

\begin{abstract}
Objective: To identify the perception of nursing professionals about drug therapy for people with mental disorders. Methods: An exploratory qualitative research was carried out in four Psychosocial Care Centers of Curitiba, Paraná, Brazil. Data, collected from January to March 2015 using an individual semi-structured interview applied to 56 nursing professionals, were submitted to qualitative data analysis and interpretation as proposed by Creswell. Results: The data were organized into three thematic categories: drug therapy improves the life of the person with a mental disorder; negative and positive consequences related to drug therapy; and drug therapy as one of the resources needed to treat mental health. Conclusion: Nursing staff perceive the importance of medications as a resource to treat people with mental disorders as psychotropic drugs minimize he acute symptoms of disorders and improve living conditions when associated with other therapeutic resources.
\end{abstract}

Keywords: Nursing, Team; Mental Health; Mental Disorders; Psychotropic Drugs.

\section{RESUMO}

Objetivo: Conhecer a percepção dos profissionais de enfermagem sobre a terapêutica medicamentosa às pessoas com transtorno mental. Métodos: Pesquisa qualitativa exploratória realizada em quatro Centros de Atenção Psicossocial de Curitiba, Paraná, Brasil. Os dados foram coletados de janeiro a março de 2015, por entrevista semiestruturada individual aplicada a 56 profissionais de Enfermagem e foram submetidos a Análise e Interpretação de Dados Qualitativos proposta por Creswell. Resultados: Os dados foram organizados em categorias temáticas: a terapêutica medicamentosa melhora a vida da pessoa com transtorno mental; consequências negativas e positivas ante a terapêutica medicamentosa; e a terapêutica medicamentosa como um dos recursos necessários ao tratamento em saúde mental. Conclusão : A equipe de enfermagem percebe o uso de medicamentos como um importante recurso terapêutico no tratamento à pessoa com transtorno mental ao minimizar os sintomas agudos do transtorno e ao possibilitar melhores condições de vida quando associados a outros recursos terapêuticos.

Palavras-chave: Equipe de Enfermagem; Saúde mental; Transtornos mentais; Psicotrópicos.

\section{Resumen}

Objetivo: Conocer la percepción de los enfermeros sobre la terapéutica medicamentosa a personas con trastorno mental. Métodos: Investigación cualitativa-exploratoria desarrollada en cuatro Centros de Atención Psicosocial de Curitiba, Paraná, Brasil. Los datos se recogieron de enero a marzo de 2015, mediante entrevista semiestructurada individual aplicada a 56 profesionales de Enfermería y se sometieron al Análisis e Interpretación de Datos Cualitativos propuesto por Creswell. Resultados: Los datos se organizaron en categorías temáticas: la terapéutica medicamentosa mejora la vida de la persona con trastorno mental; consecuencias negativas y positivas ante la terapéutica medicamentosa; $y$ la terapia medicamentosa como uno de los recursos requeridos para el tratamiento en salud mental. Conclusión: El equipo de enfermería percibe la utilización de medicamentos como un importante recurso terapéutico en el tratamiento de la persona con trastorno mental al paliar los síntomas agudos de trastorno y posibilitar mejores condiciones de vida cuando asociados a otros recursos terapéuticos.

Palabras clave: Grupo de enfermería; Salud mental; Trastornos Mentales; Psicotrópicos.
Corresponding author: Mariluci Alves Maftum. E-mail: maftum@ufpr.br

\section{Submitted on 10/05/2017.} Accepted on 01/08/2018.

DOI: 10.1590/2177-9465-EAN-2017-0294 


\section{INTRODUCTION}

Recently, mental disorders have been a focus of public health programs due to their worrisome global panorama evidenced by the high prevalence reported by epidemiological studies that describe this health condition as a threat to human development. ${ }^{1,2}$

In recent decades, according to the World Health Organization (WHO), there has been a growing increase in the prevalence of mental disorders in the world population. It is estimated that about 650 million people have some type of mental disorder, thus comprising four of the ten leading causes of incapacitation in the world. ${ }^{1,2}$

Mental disorders are classified as chronic and highly widespread, presenting different symptoms, usually associated with a combination of atypical thoughts, emotions and behaviors that affect countless personal, family and social aspects of the affected person's life. ${ }^{3}$ They are often delimited by the instability of the manifestation of symptoms as sometimes there are moments of remission and sometimes of exacerbation, characterized by delusions, hallucinations, agitation, self or hetero-aggressive behavior and social exposure. . $^{3,4}$

In this sense, the person with a mental disorder often requires continuous treatment with multiple psychosocial interventions using a multiprofessional and interdisciplinary approach with psychotherapies, group and/or individual therapies, and drug therapy, among others. ${ }^{4-6}$

Drug therapy, when applied rationally, aims to reduce the harmful symptoms resulting from the mental disorder, in order to better adapt the individual to reality. ${ }^{5}$ Medications are commonly used to treat mental health cases with their easy availability and efficacy being responsible for the widespread use of this resource. $^{7}$

Thus, without aiming to cure but to improve the quality of life of the individual, drug therapy is an important resource in mental health treatment, contributing to the physical and mental well-being, and helping in the social reinsertion and the reestablishment of the autonomy of the individual as a citizen..$^{5,8,9}$

The nursing team, as part of the multi-professional health team, plays a fundamental role in drug therapy in mental health, after all, these professionals must have an active posture and are in contact with the patient every day and so that they have experience of the use of medications and the day-to-day life of patients. ${ }^{4,5}$ Moreover, this treatment option is inserted in the professional practice of the nursing team, which should aim at humanized, systematized and integral care based on psychosocial rehabilitation supported by the precepts of the Psychiatric Reform. ${ }^{4,6,9}$

Therefore, knowing how the nursing staff perceives drug therapy in mental health care is of paramount importance, since it is up to these professionals to administer, supervise and guide the patient about the prescribed medication. In addition to clarifying the reasons for the therapeutic indication, expected effects, frequency of administration, possible side effects and adverse effects, nursing professionals should be aware of how this therapy is perceived and experienced by the person with the mental disorder, because treatment success depends on the attitudes of these professionals. ${ }^{4,6}$ Given this context, this research aimed to know the perception of nursing professionals on the drug therapy given to people with mental disorders.

\section{METHOD}

This is an exploratory qualitative research, developed in a Class II Psychosocial Care Center (CAPS) and three Class III Psychosocial Care Centers (CAPS) in the city of Curitiba, Paraná, Brazil. Sixty-two nursing professionals (23 nurses, 37 technicians and 2 nursing assistants) were invited to participate in the study: 21 in the first (8 nurses and 13 nursing technicians), 20 in the second (7 nurses and 13 nursing technicians), 18 in the third (7 nurses and 11 nursing technicians) and three in the last CAPS (one nurse and two nursing assistants). Four professionals refused to participate even after three attempts to talk to them at different times.

Nursing professionals who directly worked in the care of the people with mental disorders participated in this research. Professionals who were on vacation or on medical leave at the time of data collection were excluded. Thus, 56 nursing professionals participated in this research.

Of the 56 professionals who participated, 23 had college degrees and 33 had completed high school (31 technicians and 2 nursing assistants); 50 were female and six were male. The mean age of the participants was 38.4 years. With regard to the work shift, 32 participants worked during the day and 24 at night. The average time of working in nursing was 7.8 years; they had worked on average 1.7 years in mental health work with only 11 reported having received any kind of training, qualification or course in mental health.

Data collection was carried out from January to March 2015 using an individual semi-structured interview that was recorded and later transcribed in full. The interviews, held in a private room provided by the management inside the CAPS, were scheduled according to the availability of the interviewee.

An interview script was elaborated for data collection to characterize the participant with personal (name, telephone for contact and age) and professional data (time of working in nursing, time of working in mental health and training). The question "Tell me how you perceive the use of medications in the treatment of people with mental disorders" was used to investigate knowledge about drug treatment.

The collected data were submitted to the technique of analysis and interpretation of qualitative data as described by Creswell, which is composed of six steps: 1) organization and preparation of the data; 2) careful reading the data; 3) data coding; 4) creation of a general description of the setting; 5) representation of the general description; and 6) interpretation the data. ${ }^{10}$

Initially the interviews were transcribed in full and read, so that the relevant data could be identified and organized into sub-categories. After this, the transcriptions were reread 
more carefully to gain a general perception and a reflection on the overall understanding of the information, highlighting the ideas that were the focus of this study. Subsequently, a detailed analysis of the data was carried out in the coding process, and the material was organized into text segments based on the participant's actual language. Step 4 consisted of encoding these text segments so as to organize them into categories. In step five, the categorized data was described. The last step consisted in the interpretation and a discussion of the obtained data, which were compared with studies published in the scientific literature.

This study is part of a larger project, entitled "Adherence to the use of medication by the person with a mental disorder", approved by the Research Ethics Committee of the Federal University of Paraná (CAAE: 20816713.9.0000.0102). It was submitted and approved for feasibility analysis by the Health Education Center, Health Department of the Municipality of Curitiba. Participation in the study required the signing of an informed consent form and all ethical aspects were guaranteed according to Resolution 466/12 of the Brazilian National Health Council, which defines the guidelines and norms regulating research involving human beings. ${ }^{11}$

\section{RESULTS}

The data that emerged from the interviews about the nursing professionals' perception about drug therapy of the person with a mental disorder were grouped in three categories: drug therapy improves the life of the person with a mental disorder; negative and positive consequences related to drug therapy; and drug therapy as one of the resources needed for mental health treatment.

\section{Drug therapy improves the life of the person with a mental disorder}

According to the statements that gave rise to this category, drug therapy is important because it significantly improves the life of the person with a mental disorder, resulting in independence to develop daily activities and self-care, thus making life possible within society.

\section{[...] By using [medication], they say that they are getting} better, that they can go out on their own, go to the bank, to the market, they can go out, they are not limited. If they use psychoactive drugs, their lives will improve and they will not need to be locked indoors [...] (P1)

$[\ldots]$ I believe that without medication most of them would not be able to have a normal life in society [...] (P6)

Improvements in the interpersonal relationships that people with a mental disorder establish is also apparent, in particular interactions with relatives, other patients and the nursing team, because with the medication-related stability of the symptoms, these people communicate better, they manage to avoid conflicts and they become more receptive.
[...] There are some who do not even want to see their parents and are aggressive towards them, then, over time, they change, they embrace their mother, they talk [...], there are others who speak very badly and say things that are not true, it is because they are delirious, they are hallucinating, they say that they were hit and argued. And then we see that in time he embraces his mother or father or brother [...] (P24)

[...] We see that the medication really does work, because the patient becomes more organized, in a more stable mood, more collaborative with the nursing team, and also more involved with other patients [...] (P26)

For some participants the improvement of the person with a mental disorder provided by drug therapy at the time of a crisis shows remission of the acute symptoms of the disorder, especially when the person is admitted to the service. According to the participants, the improvement occurs when there is an immediate control of the psychomotor agitation and the aggressiveness.

[...] Patients improve, because do they not evolve to a crisis. Because the crisis is very sad, it is very traumatic. When the patient is in crisis, he becomes very upset and the medication automatically reduces his symptoms. So I think it helps a lot, the medication is important. (P13)

[...] They are a little agitated, they take the medication they sleep a little and when they wake up they are already much calmer, they can talk a little more. (P12)

Medications are needed when they are uncontrolled. When they take the medication, they become calm. (P18)

[...] There are many who see mirages of people, they hear voices controlling them. So, it helps them not to harm anyone, not to hurt others and not to hurt themselves. (P10)

The medication is very important when they have delusional speech, with hallucinations, depression, cannot sleep at night and thinking about suicide too, so they need the medication to help. If a patient wants to commit suicide and you do not administer the medication, he ends up doing it [...] (P24)

\section{Negative and positive consequences related to drug therapy}

Although drug therapy is essential to control the acute symptoms of mental disorders, it also causes significant limitations arising from side effects and adverse effects. Many patients improve but need to cope with negative effects. On the other hand, there are people who do not improve, a divergence to the expected effect.

[...] There are patients that have a lot of effects, they are tachycardic, sleepy, but it's normal, it's the effects of the medication, because the medication is like that [...] 
it improves one side, but it weakens another, so it cannot solve all problems. The patient starts to salivate, some shake very much, medications affect the mobility of the body, patients become more fragile, they do not seem to have any firmness, they move with motor coordination [...] (P17)

[...] There are some who become very sleepy, have difficulty walking, begin to salivate, instead of improving, become more agitated. (P23)

[...] They complain a lot of stomach pain, a lot of drowsiness with some medications. [...] there are other patients who adapt well, but not all [...] and I see some improvements. But there are patients where we do not see any improvement. (P30)

The characteristic of having a chronic health condition incurs difficulties in establishing the type and dose of drugs, and therefore, it is frequently altered, thus having a painful effect on the life of the person with a mental disorder.

[...] in drug treatment, the dose increases and is changed from time to time, it is complicated, it becomes a vicious cycle, he [the patient] will always be on treatment, he will never get better from the mental problem. This is painful for me. (P31)

$[\ldots]$ I think the longer the patient takes the medication, the more difficult it becomes. I think the body builds up resistance, [...] because of the length of time he is taking the medication; he becomes more resistant. (P21)

\section{Drug therapy as one of the resources needed for mental health treatment}

For participants, drug treatment should be associated with other treatment modalities, such as participation in therapeutic groups and workshops. Furthermore, the multiprofessional team should offer support to the person with a mental disorder with therapeutic listening and include the family in the treatment of the patient.

It is not only medication that helps [...] it's the work we do at CAPS, we hold workshops, we listen to them a lot. I think this helps them a lot. (P2)

The medication helps a lot because they need to take the medication; then they come to do the therapy part, do some activity, walk and go back and forth, and do some exercise. They become happy; they go there very excited, the company of others helps a lot. (P12)

In addition to the medication, the physical part, that is the body receiving the medication, there is a whole set [of aspects], the support, conversation, family, society, everything! (P5)
I think it has to encompass the medication and the technical treatment, we have a dance group, there are patients that, with the help of the medication, fit in, and there are others who do not. Just with the medication, the patient will stay sleeping at home, if not, they hold everything in too much, then they explode [...] it is good that they come to the group, so that they get out a little. (P16)

There is a perception that the drug treatment facilitates the participation of the person with a mental disorder in other therapeutic modalities offered by the service and also the establishment of bonds between the patient and the healthcare team.

These medications help in the treatment and allow a better quality of life [...] but it is not the only way, there are therapies, groups, individual conversations, other activities. But they would not be able to do that if it were not for the medication [...]. If they were not taking the medication, they would not do anything, they would not manage, they would become discouraged, nervous. (P9)

On the other hand, there were reports that advocated drug therapy as the main therapeutic resource needed to alleviate the acute symptoms of mental disorder. For them, the improvement in the symptomatological picture is conditioned only by the use of the medicine.

It is with the medication that the patient improves, because, with anything else, he does not improve; he becomes calmer; it makes him calm [...]. With medication, the patient returns to reality, does not stay so delirious, so hallucinated. I think it's because of the medication, as here in the CAPS there is not another type of therapy, even if we had, it would not help a person who is hallucinating. So it's the medication that works [...] without the medication, they only get worse, it's the only way to improve [....]. (P18)

[...] Unfortunately, it is necessary. Treatment without drugs does not work. It is impossible for you to calm down a schizophrenic patient, for example. (P31)

\section{DISCUSSION}

Drug therapy is a widely used resource and when prescribed in a coherent way, directed at the individual needs of the person with a mental disorder, it significantly improves the symptomatology of the mental disorder and thus it favors interpersonal relationships and contributes to their integration within society. ${ }^{12,13}$

It is known that the person with a mental disorder can evolve with impaired perception of reality and behavioral changes 
interfering directly in interpersonal and family relationships, autonomy and self-care. ${ }^{4}$ In these cases, the use of medication is effective because it reduces these deleterious deficiencies. ${ }^{7}$

In a study carried out in 23 people with bipolar affective disorder treated at two CAPS in the city of Fortaleza, Ceará, Brazil, the significance of drug therapy was proven, since all patients reported improvement of the symptoms of the mental disorder and their well-being after being prescribed lithium carbonate. ${ }^{9}$

Another research involving 15 people with mental disorders from a psychiatric outpatient clinic of a hospital in the interior of Rio Grande do Sul, Brazil, which aimed at understanding the meaning of medication use, reported that individuals perceive drug therapy as an opportunity to obtain a life within normality. This normality was considered to be acceptable and within society's norms. ${ }^{5}$

The immediate control of the crisis was also reported by the participants of the present research as one of the purposes of drug therapy. Given this context, it is understood that the person with a mental disorder can experience episodes of acute crises of symptoms with hallucinations, delusions, psychomotor agitation, disorganized speech, and self- or hetero-aggressive behavior. ${ }^{14,15}$ For these cases the use of medication can be considered an effective strategy in the remission of acute symptoms and thus minimize the suffering of the individual. ${ }^{16}$

The moment of crisis goes beyond the exacerbation of symptoms or an expression of a pathology, it is a unique experience that produces moments marked by fear, pain and uncertainty, and is expressed related to the particularities and the desires of each one. ${ }^{14}$ Thus, strategies to help the person in crisis often include the use of psychotropic drugs to minimize symptomatology together with embracing the patient and providing therapeutic listening as a means to reduce the suffering. $14,17,18$

This is because therapeutic listening is a therapeutic resource constituting not only of listening to what the individual has to say, but also to find meaning in what is expressed, which can minimize the acute symptoms of mental disorder such as anxiety and suicidal thoughts among others. ${ }^{18,19}$

In this perspective, some participants understand the importance of therapeutic listening in mental health care by mentioning that besides the use of medication, the establishment of links between the health professional and the person with a mental disorder through listening is fundamental, since it facilitates the introduction and acceptance of the treatment as a whole.

Coexistence with side effects and adverse effects was another perception of the nursing staff regarding drug therapy. Considering the chronicity of mental disorders, health professionals and researchers now have great concern regarding knowledge and safety related to the consequences of prolonged use of medicines. This concern is largely related to adverse and side effects that are critical to the health of some individuals. ${ }^{7}$

Prolonged use of medications can be exhausting, since it represents living with the patient for a long time, sometimes for a lifetime, with the different deleterious effects of medications that can affect self-esteem, generate hopelessness, cause discomfort, restrict daily activities and modify the social identity of the individual. ${ }^{4}$

These consequences determine the follow-up of the treatment of patients. However, in view of these negative aspects, the nursing professional, as a member of the health team, must be alert to the signs and symptoms of side effects and adverse effects, so that they are identified early or even anticipated, seeking, together with the team, strategies to minimize the harm to the person with a mental disorder. ${ }^{3,4,20}$

The dropout rate is aggravated mainly when there is a need for the use of several medications simultaneously, a common condition in mental disorders. This is because, faced with the difficulty of coping with the adverse and side effects of multiple medications, patients tend to question the real necessity of prescribed doses and their own capacity to support polymedication, which is commonly reinforced by family members, who encourage the discontinuation of drug treatment. ${ }^{17}$

In a study conducted with 563 people under treatment for mood disorders and schizophrenia in seven CAPS in the city of Pelotas, Rio Grande do Sul, Brazil, 33\% of those who took medications suffered from some side effect or adverse effect due to treatment. ${ }^{21}$

There are cases in which simultaneous prescriptions of multiple medications are necessary after the failure of monotherapy in order to treat persistent subsyndromal symptoms. This therapeutic strategy can contribute to increase the beneficial effects of treatment; however, it can cause unwanted effects and drug interactions, making it difficult for patients to adhere to drug therapy. ${ }^{17,21}$

In these cases, the nursing professional should emphasize the positive aspects of drug therapy, helping patients to reflect about the benefits that can be acquired or maintained with the appropriate use of the medicines. These benefits include improvements in interpersonal relationships, the control of seizures and the reduction or non-necessity of (re) hospitalizations; if unsuccessful, a possible replacement for the medication should be considered. $3,4,7,20$

Another negative perception of nursing professionals regarding drug therapy is the fact that the results do not match expectations, since these professionals expected total remission of the symptoms of the mental disorder. This expectation is also generated in the person with a mental disorder who often discontinues drug therapy because it is considered limited or even ineffective and the patient does not experience a complete elimination or even a marked reduction of the symptoms of the condition. ${ }^{20}$

It is known that drug therapy becomes effective and significantly reduces the symptoms of mental disorder in between 40 and $70 \%$ of cases; however, it is worth noting that these data concern a wide range of individual responses that range between the remission of symptoms to total failure of therapy. ${ }^{8}$ 
This expectation of total remission of symptoms is a result of the traditional nursing process, based on the hospital-centered model that envisions healing through the administration of medication. However, mental health nursing professionals must change this way of thinking and acting and understand that improvements of the individual lie in rehabilitative care and in the quest for autonomy. ${ }^{22}$

Some of the participants' remarks point to the need for other therapeutic resources associated with drug therapy in the psychosocial rehabilitation process, thereby corroborating to the idea that the use of psychoactive drugs is part of a specific therapeutic plan composed of other treatment modalities. On the other hand, some participants stated that symptom improvement depends on the use of medications.

The idea that drug therapy is the only or the main alternative in mental health is also shared in research conducted with people with mental disorders, which suggests that there is a possibility of living in society only with the use of medicines. ${ }^{13,14}$

It is necessary to understand that the person with a mental disorder lives with the symptoms even before seeking a health service and when experiencing the control or the absence of these symptoms using medications, the individual experiences a sense of security and freedom and from this considers the use of medication the protagonist of their therapeutic plan. ${ }^{14}$

Mental health medications are essential in the treatment of serious mental disorders. However, they are not the only possibility of treatment. It is up to the nursing professional to guide and develop other therapeutic modalities to guarantee diversity, the subjectivity and the limitations of each individual, as well as to help the patient and his relatives by providing a moment to speak, listen and express doubts and distress in relation to treatment. ${ }^{5,13,20}$

Thus, to promote effective care of the person with a mental disorder, with an emphasis on learning, understanding and the autonomous management of the drug therapy itself and the treatment as a whole, the nursing team needs to develop skills and attitudes based on scientific evidence in mental health and mental health policies aimed at improving the quality of life. ${ }^{5}$

By understanding the importance and providing other therapeutic modalities in mental health care with psychosocial interventions, such as therapeutic groups and workshops, and psychotherapies, the team assists in widening the interval between acute attacks and decreasing the severity of the episodes. This creates an environment in which the person with a mental disorder can work and discover their potential, contributing to the strengthening of their self-esteem and selfconfidence and stimulating the exercise of citizenship and interpersonal relationships. ${ }^{3,8,12}$

\section{CONCLUSIONS}

Nursing professionals perceive that the use of psychotropic drugs favors improvements in the clinical picture of the person with a mental disorder, reflecting the search for autonomy, selfcare, and interpersonal and family relationships. Therefore, the use of medications is one of the relevant therapeutic resources to control the acute symptoms of the mental disorder and enable the psychosocial rehabilitation of the person with a mental disorder.

However, drug therapy is also perceived as negative, mainly due to the need for its prolonged use and the side effects and adverse effects that may result in important limitations to the person with a mental disorder.

The findings of this research contribute to the theoreticalpractical knowledge of the nursing professional by demonstrating the relevance of the use of psychotropic drugs and the main aspects related to drug therapy of the person with a mental disorder. Based on the results obtained, there is an urgent need for nursing professionals to promote more effective strategies to maintain medication therapy because of the negative effects of the drugs in order to guarantee the well-being of the patient and his relatives and to improve or (re)establishing the autonomy and the psychosocial rehabilitation of the individual.

\section{REFERENCES}

1. Reis LN, Pereira SS, Cardoso L, Gherardi-Donato ECS. Transtornos mentais orgânicos em um ambulatório de saúde mental brasileiro. Rev Port Enferm Saúde Mental [Internet]. 2013 Jun; [cited 2014 Apr 2]; 9:4853. Available from: http://www.scielo.mec.pt/scielo.php?script=sci_art text\&pid=S1647-21602013000100008

2. World Organization Health. Investing in mental health: evidence for action. Geneva: World Organization Health; 2013. [cited 2015 Apr 21]. Available from: http://apps.who.int/iris/ bitstream/10665/87232/1/9789241564618_eng.pdf

3. Vedana KGG, Cirineu CT, Zanetti ACG, Miasso Al. Agindo em busca de alívio: enfrentamento da esquizofrenia e dos incômodos ocasionados pelo tratamento medicamentoso. Ciênc Cuid Saúde [Internet]. 2013 Apr/Jun; [cited 2015 Apr 21]; 12(2):365-74. Available from: http:// periodicos.uem.br/ojs/index.php/CiencCuidSaude/article/view/20342

4. Souza C, Vedana KGG, Mercedes BPC, Miasso Al. Bipolar disorder and medication: adherence, patient's knowledge and serum monitoring of lithium carbonate. Rev Latino Am Enferm [Internet]. 2013 Mar/Apr; [cited 2015 Apr 17]; 21(2):624-31. Available from: http://www.scielo. br/scielo.php?script=sci_arttext\&pid=S0104-11692013000200624\&In $\mathrm{g}=$ en\&nrm=iso\&tlng=en. DOI: http://dx.doi.org/10.1590/S010411692013000200021

5. Xavier MS, Terra MG, Silva CT, Mostardeiro SCTS, Silva AA, Freitas FF. The meaning of psychotropic drug use for individuals with mental disorders in outpatient monitoring. Esc Anna Nery [Internet]. 2014 Jun; [cited 2017 Jan 10]; 18(2):323-9. Available from: http://www.scielo.br/scielo.php?script=sci_arttext\&pid=S141481452014000200323\&lng=en. DOI: http://dx.doi.org/10.5935/14148145.20140047

6. Fernandes MA, Silva EM, Ibiapina ARS. Cuidado de enfermagem ao indivíduo com transtorno mental: estudo em um hospital geral Rev Interd [Internet]. 2015 Oct/Nov; [cited 2017 Jun 23]; 8(4):163-73. Available from: http://revistainterdisciplinar.uninovafapi.edu.br/index. php/revinter/article/view/797/pdf_276

7. Rajkumar RP. A patient-centered model of the action of psychotropic drugs. Pers Med Universe [Internet]. 2015 Jul; [cited 2017 Jan 19]; 4:4653. Available from: https://www.sciencedirect.com/science/article/pii/ S218649501500005X.DOI: https://doi.org/10.1016/j.pmu.2015.03.001

8. Kantorski LP, Guedes AC, Feijó AM, Hisse CN. Negotiated medication as a therapeutic resource in the work process of a Psycho-Social Care Center: contributions to nursing. Texto Contexto Enferm [Internet] 2013 Dec; [cited 2015 May 8];22(4):1022-9. Available from: http://www.scielo. br/scielo.php?script=sci_arttext\&pid=S0104-07072013000400019\&In g=en\&nrm=iso. $\mathrm{http}: / / d x$. doi.org/10.1590/S0104-07072013000400019 
9. Freire EC, Feijó CFC, Fonteles MMF, Eliza de Sá JS, Carvalho TMJP. Adesão ao tratamento medicamentoso em usuários com transtornos de humor de centro de atenção psicossocial do nordeste do Brasil. Rev Ciênc Farmac Bás Aplic [Internet]. 2013; [cited 2015 May 2]; 34(4):565-70. Available from: http://serv-bib.fcfar.unesp.br/seer/index. php/Cien_Farm/article/viewArticle/2641

10. Creswell JW. Projeto de pesquisa: métodos qualitativo, quantitativo e misto. $2^{a}$ ed. Porto Alegre: Artmed; 2007.

11. Ministério da Saúde (BR). Conselho Nacional de Saúde. Resolução № 466, de 12 de dezembro de 2012. O Plenário do Conselho Nacional de Saúde em sua $240^{\underline{a}}$ Reunião Ordinária, realizada nos dias 11 e 12 de dezembro de 2012, no uso de suas competências regimentais e atribuições conferidas pela Lei oㅜ 8.080 , de 19 de setembro de 1990 e pela Lei no 8.142, de 28 de dezembro de 1990. Considerando o respeito pela dignidade humana e pela especial proteção devida aos participantes das pesquisas científicas envolvendo seres humanos. Brasília (DF): Ministério da Saúde; 2012 [Internet]. [cited 2015 Apr 23]. Available from: http://bvsms.saude.gov.br/bvs/saudelegis/cns/2013/ res0466_12_12_2012.html

12. Xavier MS, Terra MG, Silva CT, Souto VT, Mostradeiro SCTS, Vasconcelos RO. A utilização de psicofármacos em indivíduos com transtorno mental em acompanhamento ambulatorial. Enferm Glob [Internet]. 2014 Oct; [cited 2017 Jun 14]; 36:126-37. Available from: http://revistas.um.es/eglobal/article/viewFile/201121/165641

13. Maftum MA, Alcântara CB, Capistrano FC, Czarnobay J, Ferreira ACZ, Brusamarello $T$. Uso do psicofármaco no tratamento à pessoa com transtorno mental: percepção da equipe de enfermagem. Invest Qualit Saúde [Internet]. 2016; [cited 2016 Dec 29]; 2:664-73. Available from: http://proceedings.ciaiq.org/index.php/ciaiq2016/article/view/808/794

14. Zeferino MT, Cartana MHF, Fialho MB, Huber MZ, Bertoncello KCG. Percepção dos trabalhadores da saúde sobre às crises na Rede de Atenção Psicossocial. Esc Anna Nery [Internet]. 2016 Jun; [cited 2017 Jan 25]; 20(3):e20160059. Available from: http://www.scielo.br/scielo. php?script=sci_arttext\&pid=S1414-81452016000300204\&lng=en\&nr $\mathrm{m}=$ iso\&tlng=en. DOI: http://dx.doi.org/10.5935/1414-8145.20160059

15. Almeida AB, Nascimento ERP, Rodrigues J, Schweitzer G. Intervenção nas situações de crise psíquica: dificuldades e sugestões de uma equipe de atenção pré-hospitalar. Rev Bras Enferm [Internet]. 2014 Sep/Oct; [cited 2017 Jun 14]; 67(5):708-14. Available from: http://www.scielo.br/ pdf/reben/v67n5/0034-7167-reben-67-05-0708.pdf. DOI: http://dx.doi. org/10.1590/0034-7167.2014670506
16. Estrela KSR, Loyola CMD. Administração de medicação de uso quando necessário e o cuidado de enfermagem psiquiátrica. Rev Bras Enferm [Internet]. 2014 Jul/Aug; [cited 2017 Jun 14]; 67(4):563-7. Available from: http://www.scielo.br/scielo.php?script=sci_arttext\&pid $=$ S0034-71672014000400563. DOI: http://dx.doi.org/10.1590/00347167.2014670410

17. Miasso Al, Carmo BP, Tirapelli CR. Transtorno afetivo bipolar: perfil farmacoterapêutico e adesão ao medicamento. Rev Esc Enferm USP [Internet]. 2012 Jun; [cited 2017 Jun 14]; 46(3):689-95. Available from: http://www.scielo.br/scielo.php?script=sci arttext\&pid =S0080-62342012000300022. DOI: http://dx.doi.org/10.1590/S008062342012000300022

18. Silva HHS, Silva PMC, Azevedo EB, Rocha DC, Costa LFP, Musse JO. Intervenção de enfermagem ao paciente em crise psiquiátrica nos centros de atenção psicossocial. Cogitare Enferm [Internet] 2012; [cited 2017 Jun 14]; 17(3):464-70. Available from: http://revistas. ufpr.br/cogitare/article/view/29286. DOI: http://dx.doi.org/10.5380/ ce.v17i3.29286

19. Lima DWC, Vieira AN, Silveira LC. A escuta terapêutica no cuidado clínico de enfermagem. Texto Contexto Enferm [Internet]. 2015; [cited 2017 Jun 13]; 24(1):154-60. Available from: http://www.index-f.com/ textocontexto/2015/r24154.php

20. Pedroza AP, Oliveira FB, Fortunato ML, Soares PFC. Articulação saúde mental e economia solidária: relato de projeto de inclusão social. Rev Rene [Internet]. 2012; [cited 2017 Jun 10]; 13(2):454-62. Available from: http://www.revistarene.ufc.br/revista/index.php/revista/article/ viewFile/229/pdf

21. Zago AC, Tomasi E, Demori CC. Adesão ao tratamento medicamentoso dos usuários de Centros de Atenção Psicossocial com transtornos de humor e esquizofrenia. SMAD Rev Eletrônica Saúde Ment Alcool Drog [Internet]. 2015 Oct/Dec; [cited 2015 Apr 23]; 11(4):224-33. Available from: http://www.revistas.usp.br/smad/article/view/116781. DOI 10.11606/issn.1806-6976.v11i4p224-233

22. Cavalcanti PCS, Oliveira RMP, Caccavo PV, Porto IS. O cuidado de enfermagem nos Centros de Atenção Psicossocial. Ciênc Cuid Saúde [Internet].2014 Jan/Mar; [cited 2017 Jun 10]; 13(1):111-9. Available from: http://www.periodicos.uem.br/ojs/index.php/CiencCuidSaude/article/ viewFile/19458/pdf_120. DOI: 10.4025/cienccuidsaude.v13i1.19458 